\title{
Framing a Strategy
}

\section{Exploring Faculty Attitudes toward Library Instruction and Technology Preferences to Enhance Information Literacy}

Higher education librarians and faculty members alike are faced with an everexpanding palette of technologies available for instructional use. Efforts between these two groups to collaborate in information literacy programs can greatly benefit from the incorporation of some of these new technologies. This article presents the results of a survey of 118 faculty members at Western Michigan University; conducted in 2011, it had three aims: (1) to gauge current faculty perceptions about library research instruction; (2) to determine how faculty are using technology in instruction; and (3) to examine faculty insights regarding the integration of different technological formats into future library instruction. The three technologies most preferred were online videos, personal or WMU homepages, and discussion boards. Faculty in education and social sciences were the heaviest users of technology. Looking forward, faculty were most interested in shorter, more targeted face-to-face instructional sessions and in asynchronous online instruction, such as tutorials and class guides. The University Libraries has begun to reshape its information literacy program based on the survey results, and has started to incorporate more library research instruction into the new campus learning management system. This article concludes with a series of recommendations for librarians to determine the needs of their own campuses and to integrate technologies into their information literacy collaborations with faculty.

$\mathbf{T}$ here is much truth to the old adage "Be careful what you wish for." After years of advocating for the importance of information literacy at the university level, the Western Michigan University (WMU) Libraries were successful in placing information literacy (IL) as one of the strategic goals in the University's Academic Affairs Strategic Plan in 2010. The spotlight is now on the Libraries to lead this campus-wide initiative. Adding to this challenge, the evolving use of technology in education raises the issue of how to best take advantage of technological tools and advancements to achieve our goals. Other academic libraries are likely grappling with similar issues, especially in light of the increase in online education across much of higher education. Exploring current faculty attitudes toward library research instruction and their use of technology can help librarians adjust to teaching trends within their institutions. Knowing the faculty's opinions will keep services relevant and engaging for students who are becoming more and more accustomed to asynchronous instructional formats, similar to the type of

\section{Patricia Fravel Vander Meer, Maria A. Perez-Stable, and Dianna E. Sachs}

\section{Patricia Fravel Vander Meer} (pat.vandermeer@wmich.edu) is Central Reference Services Librarian; Maria A. Perez-Stable (maria.perez -stable@wmich.edu) is Head, Central Reference Services; and Dianna E. Sachs (dianna.sachs@wmich.edu) is Instructional Services Librarian, University Libraries, Western Michigan University, Kalamazoo, Michigan.

Reference \& User Services Quarterly, vol. 52, no. 2, pp. 109-22 (c) 2012 American Library Association. All rights reserved.

Permission granted to reproduce for nonprofit, educational use. 


\section{FEATURE}

application-based tools-such as those for mobile devicesthat they practically take for granted. ${ }^{1}$ It can also shed light on new ways to collaborate with faculty through a variety of instructional methods, whether online (taught using a learning management system), hybrid (taught both face-to-face and online), or traditional instruction.

As the WMU Libraries are modifying their own IL program in response to the new University's Academic Affairs Strategic Plan, it was an opportune moment to take stock of the current program, and the ways it is perceived by the faculty. The Libraries have never surveyed the faculty at large regarding library research instruction; heretofore, the majority of data has been collected informally and anecdotally. Therefore, we developed and sent a survey to our faculty. The aim of this study was three-fold:

1. to gauge current faculty perceptions about library research instruction

2. to determine how faculty are using technology in instruction

3. to examine faculty opinions regarding the incorporation of technological formats in future library research instruction

Our goal is to use the data collected to examine our current IL program, with an eye to developing new ways to advance instruction through technologies that faculty use and/ or those they wish to see the Libraries employ in delivering library instruction. It is our hope that this study can serve as a model for others seeking to improve their IL programs based on the technologies being used by their faculty.

\section{LITERATURE REVIEW}

A scan of the literature of the past thirty years showed a significant number of articles that address faculty attitudes toward library instruction and which informed this study. Maynard (1990) surveyed the faculty at The Citadel regarding their attitudes toward library instruction. Maynard compared the English instructors to the rest of the faculty in the institution. Although the sampling size was small, nearly all the respondents thought instruction was important and they were satisfied with the librarians' instruction. There was a difference, however, in their attitudes toward collaboration with a librarian-while 75 percent of the English faculty thought that both librarians and faculty members should be involved in the research instruction, only 40 percent of the non-English faculty shared the opinion that collaboration was desirable. ${ }^{2}$

Thomas (1994) conducted a study in 1982, and again in 1990, which analyzed faculty attitudes toward library research instruction at California State University Long Beach. One finding was that in 1982, only 16 percent of the faculty indicated the curriculum was too full to accommodate library instruction, but in 1990, this had jumped dramatically to 53 percent. ${ }^{3}$ Today, this is still a recurring theme in the literature.
In other words, while faculty may value library instruction, they continue to find it hard to fit a session into their alreadysaturated semester.

The most relevant study to our research regarding faculty attitudes toward library instruction was conducted by Cannon at York University in Toronto (1994) and served as a foundation for several subsequent articles. She developed a twenty-item survey sent to full-time faculty in the social sciences and humanities. The aim of the survey was to better understand faculty perceptions regarding students' research skills, preferred methods of library instruction to meet student needs, and faculty-librarian collaboration. Forty-four percent of respondents indicated that a librarian had taught a research session for their classes, with the English and history departments as the two most frequent requestors. Cannon's results also indicated that a significant majority of the respondents reported being very open to partnering more closely with librarians. ${ }^{4}$

Leckie and Fullerton (1999) conducted a survey based on Cannon's questionnaire that targeted faculty awareness of, and attitudes toward, library instruction as it related to science and engineering undergraduate students at two Canadian colleges. They also queried the faculty's perceptions of the role of science and engineering librarians in library instruction. Although many faculty thought library instruction was necessary for undergraduates, relatively few requested instructional sessions. Similar to Cannon's findings, Leckie and Fullerton discovered that faculty had a difficult time scheduling a session into an already-full semester. Of interest is that some faculty expressed resentment regarding library instruction, stating they thought students should have learned this in high school. ${ }^{5}$ Gonzales (2001) also built upon Cannon's research by expanding the questionnaire to include faculty in all disciplines at the University of Southern Colorado. Gonzales acknowledged that the small number of responses (44) made it difficult to draw conclusions in some areas, yet interesting information came to light. For example, a high proportion of faculty who requested library instruction also reported being heavy library users. ${ }^{6}$

In 2005, Singh published the results of a large-scale research study involving mass communication and journalism faculty from schools across the United States. Faculty responded to a survey about their use of library instruction, their students' IL skills, and the impact of the instruction on student performance. Interestingly, this study brought to light the increasing trend of IL and research skills being tied into academic program, college, and university accreditation. ${ }^{7}$ That same year, Manuel, Beck, and Molloy (2005) reported on research that differed from other studies in that it focused on college faculty who were heavy users of library instruction. Their method was distinctive because they used face-to-face interviews, rather than a survey, to gauge faculty opinions on such items as the importance of library instruction, best and worst experiences, and the effects of the instruction on their students. The top reasons why faculty appreciated library instruction included the need to develop student research skills, 
a need to combat the overreliance on the free Internet, and the value of library instruction for fostering college success. ${ }^{8}$

Another study based on Cannon's work was conducted by Hrycaj and Russo (2007) at Louisiana State University. ${ }^{9}$ Like Gonzales, they targeted the entire faculty at their institution. When asked to specify what information their students needed the most help with, faculty responded that the top two needs were finding periodical articles ( 85 percent) and evaluating resources (79 percent). ${ }^{10}$ As in other surveys, there appears to be great faculty interest in online tutorials as a delivery method for library instruction.

DaCosta (2010) also investigated attitudes of faculty toward library instruction in key areas. However, this study was unusual in that it compared findings from institutions in two countries-De Montfort University in England and the College of New Jersey in the United States. Faculty at both schools were in agreement regarding the notion of conducting formal assessment of their students' abilities to conduct library research-85 percent of the British and 91 percent of the American faculty agreed that students would learn research skills better if they were tested on their knowledge. There were other similarities in the results, notably that faculty in both countries placed a high value on students' research skills. However, this is contradicted by the fact that a relatively small number of instructors in this study actually requested library instruction. ${ }^{11}$

In reference to the second part of our study that addressed the faculty use of technology in instruction, we found numerous articles that discussed the use of a specific technology by faculty, such as electronic lecture capture and iClickers. However, we only identified a few key articles and reports that were broad in scope, covering faculty use of a variety of technologies, which was of greatest interest to us. In Campus Computing 2010, Green discussed the results of the 21st National Survey of Computing and Information Technology in American Higher Education. This annual study presents an excellent overview of information technology usage, policy issues, and trends in higher education, including data on learning management systems, the campus use of mobile applications, and faculty use of technologies such as classroom clickers, ePortfolios, Facebook, Twitter, and wikis. ${ }^{12}$ Young (2010) reported on another national study, the Faculty Survey of Student Engagement (FSSE), and presents figures on the percentage of faculty who use technology such as learning management systems, collaborative editing software (e.g. wikis), blogs, classroom clickers, video conferencing, Internet phone chat, and video games. ${ }^{13}$ Both studies showed that learning management systems were, by far, the technology that faculty use most often in their instruction.

In addition to discussion of the use of technology in education as reported in the FSSE, Guidry and BrckaLorenz (2010) included data on student engagement of academic technologies garnered from the National Survey of Student Engagement (NSSE). Using both studies, they compared patterns of student and faculty use of the same technologies, including an analysis by academic discipline. They found that the use of technology varied significantly among students and faculty in different academic disciplines. ${ }^{14}$

Regarding the use of Web 2.0 technologies in higher education, McGee and Diaz (2007) also addressed the disparity between students' and faculty's use of technology. They also noted that some faculty who want to incorporate technological innovations may be challenged because their institutions are slower than others to adopt and support new instructional technologies. The authors outlined the importance of gauging current faculty use of technology and describe various approaches to capturing this data, such as student and faculty surveys, focus groups, and interviews. Selecting the right technology requires compatibility among the instructor's teaching style, the course content, and the learner's needs. ${ }^{15}$

\section{BACKGROUND AND METHOD}

After a review of the literature, we developed a nineteenquestion online survey (see appendix A) using SurveyMonkey. ${ }^{16}$ The anonymous survey was approved by WMU's Human Subjects Institutional Review Board (HSIRB). The purpose was to identify faculty opinions and perceptions of library instruction and their use of technology in instruction. We used a combination of multiple choice and open-ended questions. Several questions $(8,12,13,14,15$, and 16) were based on the questionnaire developed by Cannon at York University. ${ }^{17} \mathrm{~A}$ distinctive feature of our survey, however, was the incorporation of questions designed to explore the use of technology in instruction by the faculty, and their attitudes toward the applications of new technologies and formats in library instruction.

During the 2010-11 academic year, WMU had 866 fulltime faculty members and 25,045 students. WMU is a Carnegie Foundation for the Advancement of Teaching research institution, one of 76 such public institutions in the nation, and offers 140 bachelor, 69 master, and 29 doctoral degree programs.

In spring 2011, we surveyed the teaching faculty in all seven academic colleges: Arts and Sciences, Aviation, Business, Education and Human Development, Engineering and Applied Sciences, Fine Arts, and Health and Human Services. We did not include the twenty-five library or the nine counseling center faculty members (because they do not generally teach semester-long courses), for a new total of 832 possible participants. Since the volume of email that faculty receive is so overwhelming, we opted to send the survey via the departmental office managers, hoping this personal contact would yield a greater rate of return. Before sending out the survey, we contacted each departmental administrative assistant by telephone to solicit and confirm their cooperation. We asked them to forward the email with the survey to their faculty. The email went out in mid-March 2011, with a suggested return date of two weeks. In view of the initial low response rate, a fortnight later we asked the library liaisons to send out a reminder to their respective departments. We left the survey open until mid-May 2011 to catch any delayed responses. 


\section{FEATURE}

\section{SURVEY RESULTS AND DISCUSSION}

\section{Demographics}

We received 118 valid responses from full-time faculty members, for a response rate of 14.2 percent. We received only eight responses from part-time faculty members and six from graduate student instructors. Since there were not enough responses from these groups to draw meaningful conclusions, we focused exclusively on the full-time instructors. Although the overall response rate was not as high as we had hoped, the number of responses was sufficient to highlight key issues and practices. Since the College of Arts and Sciences contains a wide variety of disciplines, we divided this college into three categories for the purpose of data analysis: humanities, social sciences, and natural sciences/mathematics. Faculty members in all academic colleges except for the College of Aviation responded, but the full-time faculty members in the College of Aviation comprise only 2.4 percent of the total teaching faculty. In addition, because the response rate varied widely between the colleges, we cannot guarantee that the participants represent the "average" faculty members at WMU. However, given the total number of responses, we feel comfortable drawing some conclusions to guide future decision-making.

Figure 1 shows the number of respondents by college, including the three-way division of the College of Arts and Sciences. We also asked respondents how many years they had taught at the post-secondary level. The two largest categories, comprising 75 percent of the respondents, were almost evenly split between those having 11 to 20, or $21+$ years of teaching experience. The next largest group, 14 percent, had 6 to 10 years experience, while the remaining 11 percent had five or fewer years of experience.

\section{Faculty Perceptions and Practices Related to Student Research and Library Instruction}

\section{Student Research Practices and Skills}

How do faculty perceive their students' abilities to conduct research? We were particularly interested in the responses to this question to target specific areas for improvement and better market our services. When faculty were asked if their courses had assignments that required searching for and using information beyond the textbook and course readings, nearly 84 percent replied that they required this in half or more of their courses. Faculty were then asked to rate their students' abilities to find information using either library resources or Internet sites such as Google. On a five-point scale ranging from unsatisfactory to excellent, faculty ranked freshmen and sophomores below satisfactory levels for finding information using the library or public Internet sites. Juniors and seniors were also ranked below satisfactory using the library, but fared slightly above satisfactory in Internet searching. Faculty ranked graduate students' research skills as above satisfactory in both categories, though they were scored higher in

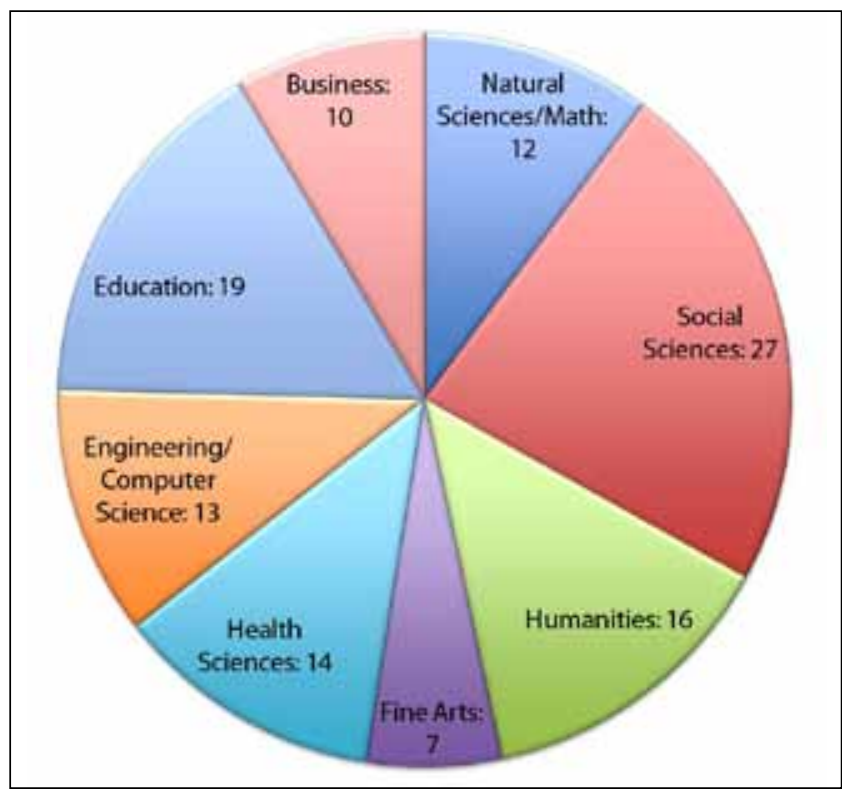

Figure 1. Number of Respondents by Discipline

researching on the Internet than in the library. These results are in keeping with research studies by Cannon, Leckie and Fullerton, Gonzales, and Hrycaj and Russo who all reported that faculty mostly lacked confidence in their students' library research skills. ${ }^{18}$ On the whole, faculty indicated that students at all levels were better at finding information through the free Internet than through the libraries. This could serve as an entrée for librarians to market instructional services to faculty that would teach students to better use the scholarly resources made accessible by academic libraries.

Using a scale of "not at all important," "minimally important," "important," and "very important," faculty were asked to place a value on the following student skills:

- develop a workable research question

- select and use appropriate tools to find information

- evaluate information sources

- correctly cite sources

- avoid plagiarism

Faculty respondents, nearly unanimously, indicated that all of these skills were either important or very important, with evaluating information sources and avoiding plagiarism tied as the most important skills to have. These were followed closely by selecting and using appropriate information tools, correctly citing sources, and, finally, developing a workable research question. The usefulness of these student skills is in keeping with those reported by Hrycaj and Russo, and Manuel, Beck, and Molloy. ${ }^{19}$

\section{Library Instruction Use and Preferences}

Moving from the theoretical into the practical realm, we asked 
the faculty what types of library research instruction they had taken advantage of in the past four years and what they might be interested in using in the future.

As seen in table 1 , nearly 41 percent of the faculty who responded to the survey have never used library instruction. Of those who have, the most popular method of instruction (42 percent) was in-library instruction, while nearly onefourth of the faculty indicated that a librarian had provided instruction in their classroom. The next most-used methods were librarian-created class guides, students voluntarily attending an out-of-class session, online tutorials/podcasts, video conferencing, and librarian presence in Elearning, WMU's learning management system.

Since two-fifths of the responding faculty have not used library instruction in the past four years, there appears to be a disconnect between the reported value that instructors place on students' library research proficiencies as discussed above and the actual use of library instruction to teach these skills. This phenomenon was mentioned in other library studies including Hrycaj and Russo, and Singh. ${ }^{20}$ So why are faculty not availing themselves of library instructional services? When asked, the response given most often was that they were unaware of the service. The next most-cited reasons were that they did not want to give up class time and that library instruction was not relevant in their courses; some faculty indicated that they preferred to teach research concepts themselves. Overall, similar reasons were also reported by Maynard, Hardesty (1995), Leckie and Fullerton, and Feldman and Sciammarella (2000). ${ }^{21}$

The final grouping of responses reflected a "NIMBY" (not in my backyard) philosophy, described by Hrycaj and Russo, and Thomas, ${ }^{22}$ encompassing the belief that students have learned the concepts in an earlier class, that it is the students' responsibility to learn research skills on their own, or that students indicated that they already knew how to conduct library research. Regarding this final reason, some faculty admitted in their comments that while their students claimed they knew how to research, this assumption was, as one respondent said, not "well founded." Another remarked, "Students think they know what to do (graduate students) and it is often late into the semester that I discover they really have no clue." Is this phenomenon self-perpetuating? In 1986, Mellon reported that students were reluctant to inform their instructors that they really did not know how to conduct library research. Some of the reasons included were " . . . a feeling that other students were competent at library use while they alone were incompetent, that this lack of competence was somehow shameful and must be kept hidden, and that asking questions would lead to a revelation of their incompetence." ${ }^{23}$ These student perceptions could be the subject of a stimulating dialogue with faculty, and an opportune occasion to promote library instruction to faculty.

To advance the University's IL initiative, we asked faculty what types of instruction would be of interest to them in the future. Table 2 shows that online class guides generated the most interest, followed by an equal amount of interest in

\section{Table 1. Faculty Use of Library Research Instruction}

\begin{tabular}{lc}
\hline Use & \% of Faculty \\
\hline Brought my class to library & 42.37 \\
\hline No library instruction & 40.68 \\
\hline Librarian came to my classroom & 22.88 \\
\hline Librarian created online class guide & 12.71 \\
Students attended optional session & 9.32 \\
\hline Librarian developed tutorial/online instruction & 8.47 \\
\hline Librarian met class via video conference & 1.69 \\
\hline Librarian was present in my online course & 0.85 \\
\hline
\end{tabular}

online instruction such as tutorials or podcasts and a thirtyminute session by a librarian in their regular classroom. Next, they indicated interest in their students voluntarily attending an out-of-class session, bringing their class into the library for instruction, and a longer than thirty-minute librarian visit to their classrooms. The two formats chosen the least often were video conferencing and having a librarian participate in Elearning.

It is interesting to note that the types of instruction that faculty most prefer do not infringe too much on their closely guarded instruction time. For the most part, faculty appear to be interested in asynchronous and technologically driven library instruction. Having a librarian embedded in Elearning was the notable exception to this pattern. It was the least preferred method even though it does not detract from instructional time. This may be influenced in part because not all faculty are conversant with Elearning and may not use it in their classes; in fact, of those faculty who have used Elearning, nearly half were either somewhat or very interested in having a librarian participate in their online course. It is possible that faculty and librarians have different ideas of what is involved in having a librarian embedded in Elearning. While most WMU librarians would envision filling a supplementary or temporary role in Elearning, some faculty may imagine that librarians would constitute an "outside" presence in their dayto-day instructional transactions that might challenge their authority and autonomy as the course instructor. This reflects what Farber (2004) wrote about faculty culture in general "that most faculty members don't feel comfortable sharing their classes with others. They're used to — and enjoy-the control, the independence they have." ${ }^{24}$ In any case, with the consistent expansion of online instruction across academe, this potential avenue for library instruction needs to be further studied and developed.

\section{Faculty Satisfaction with Library Instruction and Suggestions for Improvement}

Ninety-eight percent of the faculty stated that, overall, they found library instruction useful. When asked to relate what 


\section{FEATURE}

\section{Table 2. Faculty Interest in Library Research Instruction}

\begin{tabular}{lc}
\hline Instruction Type & $\begin{array}{c}\text { Perceived } \\
\text { Interest* }\end{array}$ \\
\hline Librarian creates online class guide & 117 \\
\hline Librarian develops tutorial/online instruction & 110 \\
\hline Librarian comes to my class <30 minutes & 110 \\
\hline Students attend optional session & 105 \\
\hline Bring my class to library & 89 \\
\hline Librarian comes to my class $>30$ minutes & 75 \\
\hline Librarian meets class via video conference & 50 \\
\hline Librarian present in my online course & 49 \\
\hline
\end{tabular}

* Perceived interest was calculated by assigning a value to each faculty response. Responses of "very interested" were assigned a value of 2; responses of "somewhat interested" were assigned a value of 1 ; responses of "not interested," or those left blank, were assigned a value of 0 and therefore were not counted.

they found beneficial about their experience with library research instruction, by far, most faculty appreciated information about the wide range of resources available and the most appropriate databases. One faculty member commented that the students "became willing to work a little harder in order to find sources very close to their interests, and were less willing to compromise and accept something more easy to find that did not quite answer their inquiry issues." Many respondents also mentioned they liked instruction related to developing search strategies, including elements such as narrowing a topic, use of keywords, truncation, and Boolean logic. Other aspects they liked encompassed the hands-on active learning component and having the instruction tailored specifically to the course. These reasons were also mentioned in the focus groups that Manuel, Beck, and Molloy reported on in 2005. ${ }^{25}$

Of note were five faculty members who mentioned they valued the instructional session not only for their students, but also for their own edification. The sessions helped them keep up-to-date with subject-specific resources in their fields, something also described by Leckie and Fullerton in 1999. ${ }^{26}$ Badke (2005) underscored this when he wrote, "Faculty are recognizing that the very tools that are their stock in trade-journals, library catalogs and indexes-have not only gone electronic but have become so complex that their own research could well be hampered by their lack of knowledge. ... Librarians to the rescue." ${ }^{27}$ In addition, respondents mentioned that they valued having their students learn about plagiarism, interlibrary loan, citing references, and Ask-a-Librarian services. One faculty member commented on the perils of foregoing library instruction: "I tried doing without this opportunity last semester when I had a group of . . . students who maintained that they did not need help using the library to search for sources. After I read their projects I regretted that choice."

Regarding the benefits of research instruction, one graduate-course instructor wrote, "The mood in the room went from anxious to comfortable to excited and happy as the students gained skills and found sources." When asked how library instruction could be improved, some of the more interesting suggestions were to provide the following:

- further differentiation between the public and private web

- more explanation of how to cite electronic articles

- "graduating" library instruction between beginning and advanced students to avoid redundancy

- closer collaboration between the instructor and librarian in planning a session that addresses the course's needs

- additional discipline-specific, user-friendly online tutorials

- increased focus on evaluating sources

- grading or formal assessment of instruction, e.g., a certificate of completion of research skills

While we have already made inroads in some of these areas, these suggestions emphasize the need for continued improvement and consistency across the IL program.

\section{Faculty Use of Technology}

\section{Elearning}

A key component of this study was to examine faculty use of technology to plan effective library instructional services. Since Elearning (WMU's learning management system) has become such a major part of college teaching, we specifically asked if faculty used Elearning in the form of an online class, a hybrid course, as a supplement to a traditional class, or not at all. As a point of reference, during the 2011 calendar year, WMU offered 10,104 classes, of which 529 were offered online, about 5.24 percent of the total offerings. The number of classes using Elearning-including as a supplement to traditional courses-has increased substantially over the last several years. Going forward, the use of this technology is expected to rise even further, since as of 2012, all WMU courses automatically have an Elearning "shell." All faculty are now required to submit grades via Elearning and increased familiarity with the system may make it easier for more faculty to incorporate Elearning into their instruction.

As evident in figure 2, the College of Education and Human Development was, by far, the leader in using Elearning to teach online courses, with nearly 60 percent reporting that they used this method. Both the Colleges of Health and Human Services and Education and Human Development used Elearning in hybrid classes to a significant degree. In general, the most popular use of Elearning was as a supplement to face-to-face classes, with the health services faculty reporting 100 percent use, followed by business and humanities, at approximately 70 and 60 percent, respectively. The percentage of faculty teaching online or hybrid courses did not significantly vary by years of teaching, although faculty with ten or fewer years of experience were more likely to use Elearning to supplement traditional face-to-face teaching. In 


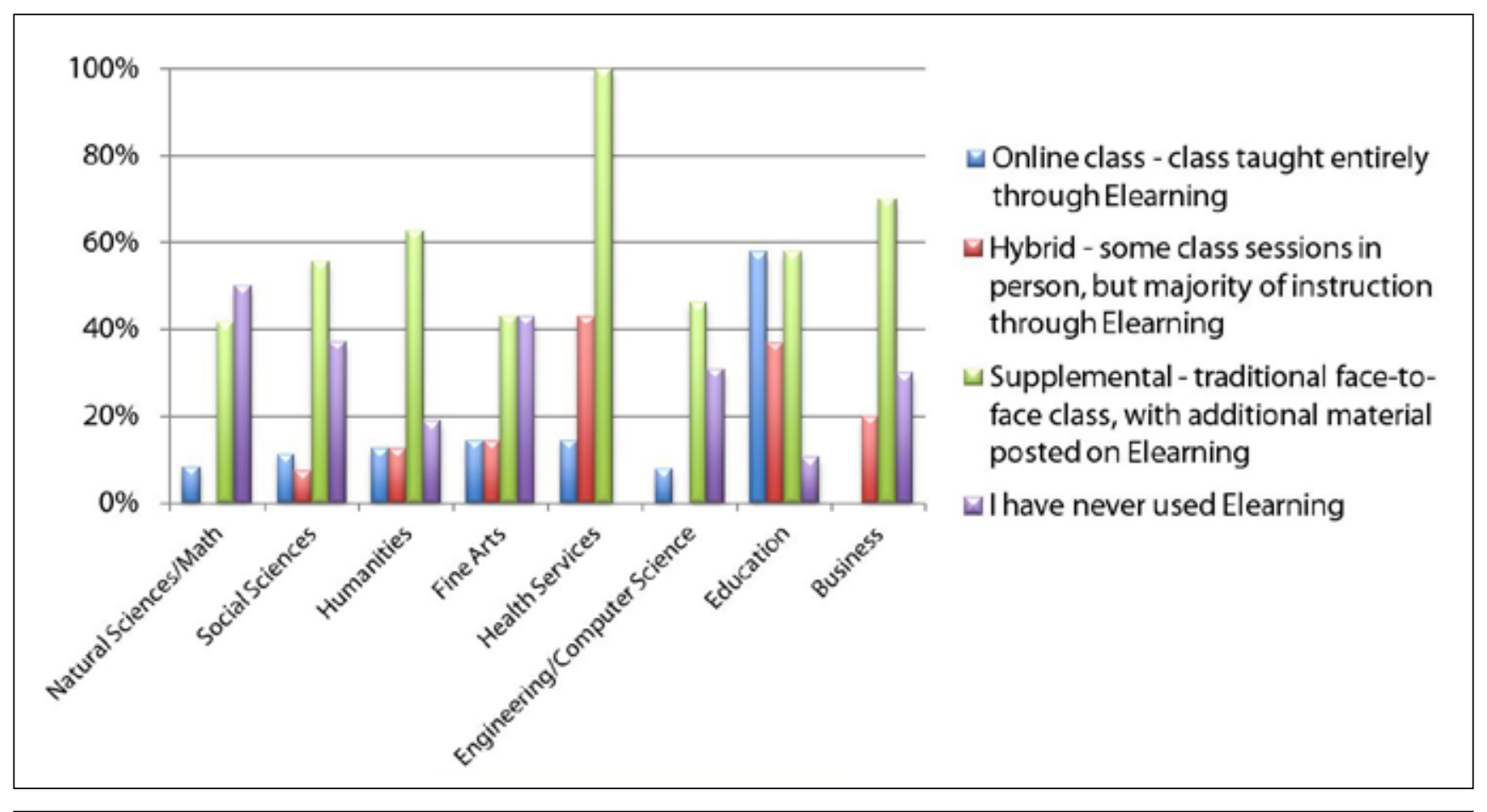

Figure 2. Faculty Use of Elearning (LMS)

the category "I have never used Elearning," there appeared to be a pattern-the longer the faculty members had taught, the less likely they were to use Elearning in their teaching at all.

The steadily increasing importance of learning management systems in higher education is documented by Green who reported that in 2000, only 14.7 percent of college courses used a learning management system, but by 2010 , this number had grown to 58.6 percent. This same national report also disclosed that 66.2 percent of the colleges and universities surveyed indicated the existence of a strategic plan to implement a learning management system. ${ }^{28}$ Similar to our findings, Young, reporting on another national assessment-the 2009 Faculty Survey of Student Engagement (FSSE) - indicated that 72 percent of the 4,600 respondents from 50 US colleges and universities use learning management systems. ${ }^{29}$

\section{Different Technologies in the Classroom}

Overall, what specific technologies do WMU faculty use in their classrooms? As apparent in table 3, Elearning was, without a doubt, the most commonly used. Other popular technologies were online or embedded videos, personal webpage or WMU "homepage," discussion boards/forums, and electronic reserves. Not as prevalent were podcasts, video conferencing, social networking sites, and blogs.

The faculty's use of social networking sites may be in response to the behavior of young adults, as reported by Lenhart (2009) in a Pew memorandum, which stated that
75 percent of 18-to-24-year-olds use this technology. ${ }^{30}$ Smith and Caruso (2010) indicated that 90 percent of the undergraduate students responding to an EDUCAUSE Center for Applied Research (ECAR) survey stated that they make use of text messaging and visit social networking sites on a daily basis; furthermore, two-thirds of these students own Internet-capable mobile devices. ${ }^{31}$ Green, in Campus Computing 2010 , reported that 85 percent of the colleges and universities surveyed maintained a formal presence on Facebook; in addition, there was a large increase in the institutional use of Twitter and YouTube from 2007 to 2010. ${ }^{32}$ It would seem that social networking only stands to rise in popularity, aided by the affordability of, and explosion in, the ownership of hand-held devices.

The technologies used least often by WMU faculty were wikis, iClickers, and RSS feeds. This is consistent with the FSSE findings that also showed relatively low use of these technologies, with 16 percent of the faculty using collaborative editing software, including wikis; 13 percent respectively using blogs and student response systems such as iClickers; and 12 percent using video conferencing or Internet phone chat such as Skype..$^{33}$ Despite the reported low use of these technologies by faculty, it appears that student use may be much higher. Smith and Caruso noted that 40 percent of students contribute to wikis, 40 percent use Skype or similar services, and 36 percent engage in blogging, although not necessarily for educational purposes. ${ }^{34}$

The reported use of different technologies by discipline was somewhat surprising. We suspected that the science, engineering, and computer science faculty would be more 


\section{FEATURE}

\begin{tabular}{lc}
\hline Table 3. Percent of Faculty Using Technologies \\
\hline Technologies & $\begin{array}{c}\text { \% of Faculty } \\
\text { Using }\end{array}$ \\
\hline Elearning & 72.03 \\
\hline Online or embedded videos & 46.61 \\
\hline Personal webpage or WMU "homepage" & 42.37 \\
\hline Discussion boards/forums & 41.53 \\
\hline Electronic reserve items & 30.51 \\
\hline Podcasts & 14.41 \\
\hline Video conferencing & 14.41 \\
\hline Social networking sites (Facebook, Twitter, & 11.86 \\
Delicious, etc.) & 11.02 \\
\hline Blogs & 6.78 \\
\hline Wikis & 5.93 \\
\hline iClickers & 4.24 \\
\hline RSS feeds & \\
\hline
\end{tabular}

conversant with and inclined to use different technologies in their classrooms, but this proved not to be the case. Table 4 shows that education and social sciences faculty were the highest users of a variety of technologies, followed by business, humanities, fine arts, health services, engineering/computer science, and natural sciences/mathematics.

Guidry and BrckaLorenz reported on eighteen American colleges and universities that responded to both the FSSE and the NSSE in 2009. For the most part, the data regarding faculty technology use by discipline did not match our findings. However, in both studies, education faculty were the top users of technology. In the 2009 survey, education was followed by arts and humanities, engineering, biological sciences, social sciences, and a tie between physical sciences and business. ${ }^{35}$

Table 5 illustrates faculty use of specific technologies by discipline. Online or embedded videos, as mentioned earlier, were used by many faculty across all disciplines. Personal or WMU homepages were also used by a fair number of faculty, ranging from a low of 20 percent in business to 54 percent in engineering and computer science. The use of electronic reserves seemed to be discipline-specific and was employed most often by social sciences, health services, and education faculty. Despite some unenthusiastic faculty comments, there was considerable usage of discussion boards/forums-this ranged from 84 percent in education, 44 percent in social sciences, 43 percent in health services, 40 percent in business, to a low of 15 percent in engineering and computer science. Social networking was used by 43 percent of faculty in fine arts and 30 percent in business, but then interest dropped dramatically. Faculty in engineering/computer science, fine arts, and business used podcasts a fair amount, but usage of RSS feeds, wikis, videoconferencing and iClickers was relatively low across most disciplines. This provides librarians a chance to offer instruction services through different
Table 4. Technology Use by Discipline

\begin{tabular}{lc}
\hline Discipline & $\begin{array}{c}\text { Avg. No. of Technologies } \\
\text { Used Per Faculty Member }\end{array}$ \\
\hline Education & 3.84 \\
\hline Social Sciences & 3.30 \\
Business & 3.10 \\
\hline Humanities & 3.06 \\
\hline Fine Arts & 2.86 \\
\hline Health Services & 2.64 \\
\hline Engineering/Computer Science & 2.46 \\
\hline Natural Sciences/Mathematics & 2.00 \\
\hline
\end{tabular}

technological formats based on the technology employed by faculty in each discipline.

\section{Faculty Success with Technology}

Of special interest was the faculty's assessment of which technologies they found to be the most successful in their teaching. Since faculty chose to comment on different technologies, we were only able to obtain a limited number of opinions on each. Aside from Elearning, the top three technologies that faculty deemed the most successful were online or embedded videos, electronic reserves, and personal homepage or faculty homepage, with 26, 15, and 12 faculty members, respectively, reporting a positive experience, and with no one expressing a negative one. When commenting on the use of online videos, faculty used words such as "illustrative," "motivating," "convenient," and "economical," and indicated videos were useful for "changing up" the presentation and for generating discussion of controversial issues. Fifteen respondents indicated success with discussion boards/forums, but three did not. For example, one faculty member noted that the online discussion led to increased student engagement and expression, while those less enamored with this technology mentioned issues such as awkward navigation, too labor intensive for faculty to monitor, the threads in discussions simply "breaking down," and the challenge of keeping students focused without the instructor appearing too "heavy handed." Librarians who wish to use these technologies in library instruction, particularly in collaboration with faculty, should be mindful of these observations.

Video conferencing received some mention-eight respondents liked it, one did not. One person reported that students enjoyed the ability to Skype with an author about a book they had read in class. Another mentioned the value of video conferencing to enable student participation in international events. Although several faculty indicated success with blogs, others were not so keen. One commented that blogs were a "uniform disaster" in that they were treated like journals with very informal language and little thought given to what was posted. Another said the blogs were highly 
Table 5. Faculty Use of Specific Technologies by Discipline

\begin{tabular}{|c|c|c|c|c|c|c|c|c|}
\hline Discipline & $\begin{array}{l}\text { Natural Sci/ } \\
\text { Math }\end{array}$ & Social Sci & Humanities & Fine Arts & $\begin{array}{l}\text { Health } \\
\text { Services }\end{array}$ & $\begin{array}{c}\text { Eng/ } \\
\text { Comp Sci }\end{array}$ & Education & Business \\
\hline Elearning & $50 \%$ & $63 \%$ & $81 \%$ & $57 \%$ & $100 \%$ & $69 \%$ & $89 \%$ & $80 \%$ \\
\hline Online or embedded videos & $42 \%$ & $44 \%$ & $63 \%$ & $43 \%$ & $43 \%$ & $31 \%$ & $63 \%$ & $60 \%$ \\
\hline Podcasts & $8 \%$ & $15 \%$ & $13 \%$ & $29 \%$ & $0 \%$ & $31 \%$ & $11 \%$ & $20 \%$ \\
\hline Blogs & $0 \%$ & $19 \%$ & $19 \%$ & $14 \%$ & $0 \%$ & $0 \%$ & $5 \%$ & $30 \%$ \\
\hline RSS feeds & $0 \%$ & $7 \%$ & $0 \%$ & $0 \%$ & $0 \%$ & $8 \%$ & $5 \%$ & $10 \%$ \\
\hline Wikis & $0 \%$ & $11 \%$ & $6 \%$ & $14 \%$ & $0 \%$ & $15 \%$ & $5 \%$ & $0 \%$ \\
\hline Discussion boards/forums & $17 \%$ & $44 \%$ & $31 \%$ & $29 \%$ & $43 \%$ & $15 \%$ & $84 \%$ & $40 \%$ \\
\hline $\begin{array}{l}\text { Personal webpage or WMU } \\
\text { "homepage" }\end{array}$ & $33 \%$ & $52 \%$ & $50 \%$ & $43 \%$ & $21 \%$ & $54 \%$ & $47 \%$ & $20 \%$ \\
\hline Video conferencing & $25 \%$ & $19 \%$ & $13 \%$ & $0 \%$ & $7 \%$ & $8 \%$ & $21 \%$ & $10 \%$ \\
\hline iClickers & $17 \%$ & $0 \%$ & $6 \%$ & $0 \%$ & $0 \%$ & $15 \%$ & $5 \%$ & $10 \%$ \\
\hline Electronic reserve items & $8 \%$ & $48 \%$ & $31 \%$ & $14 \%$ & $43 \%$ & $8 \%$ & $42 \%$ & $10 \%$ \\
\hline Social networking sites & $0 \%$ & $11 \%$ & $0 \%$ & $43 \%$ & $7 \%$ & $8 \%$ & $5 \%$ & $30 \%$ \\
\hline
\end{tabular}

Note: Faculty could select multiple technologies, leading to totals higher than $100 \%$

unsuccessful because "students did not take them seriously, or viewed them as one cut above social networking, and so were not written with scholarly tone and approach." A third mentioned that blogs were difficult to grade. Regarding the use of iClickers, one respondent expressed frustration that, at the time of the survey, the institution had not selected one single type to support.

\section{WHAT'S NEXT? MOVING FORWARD, RECOMMENDATIONS, AND CONCLUSION}

\section{Framing a Strategy}

When developing and revising their strategic plans for delivering library instruction, librarians should consider current faculty attitudes toward library instruction and their use of different instructional technologies. The data that the WMU Libraries collected has been used to improve the Libraries' IL programming in both broad and specific ways, and has helped to guide efforts to align the IL program with the University's strategic plan.

Although the data, somewhat predictably, indicated that faculty lacked confidence in their students' library research skills, faculty also felt that students at every level were better at finding information using the public Internet than through the libraries. This dovetailed with a variety of comments made by the respondents that suggested librarians should further differentiate between the public and private web, and increase focus on how to evaluate sources. This has prompted WMU librarians to provide more emphasis on critical thinking and the value of using information made available through library channels.

Even though we have certainly not given up instruction in the library, the data also indicated that faculty would like to have a librarian come to their classroom-preferably for 30 minutes or less-rather than give up an entire class period to bring their students to the library. We are working to inform the faculty that we offer this shorter option, and it is already gaining in popularity. In fact, we noticed an increase in the number of faculty requesting this service shortly after we administered our survey! An added benefit of taking the instruction "on the road" is that students are typically more comfortable in their own classroom and are more engaged and willing to participate in the session.

Challenges arise in teaching research sessions outside the library, especially when the librarian lacks familiarity with the classroom space and technology. Since every classroom is configured differently, and often faculty provide their own laptops to project, one never knows what one might encounter. In addition to coordinating the lesson plan with the faculty member, it is often necessary to coordinate the technology as well.

A major advantage of offering instruction outside of the library is being able to accommodate large lecture classes that do not fit into the library's classroom. However, these large classes present some challenges in that one cannot easily develop an engaging, active learning environment where students can receive individual attention. Here is an opportunity to get help from technology such as classroom clickers. In line with the national trend, the iClicker classroom response system is on the rise at WMU and the Libraries are considering making greater use of this tool to increase active learning.

In keeping with faculty preferences for asynchronous instruction, the Libraries continue to enhance and promote their substantial, six-module tutorial, ResearchPath ${ }^{36}$ that is used by thousands of students each year. WMU librarians are also spending more time developing online tutorials and 


\section{FEATURE}

videos, and increasing the Libraries' presence in online courses. This includes the use of the software Jing (free software) and Adobe Captivate (available for purchase). ${ }^{37}$ Jing allows the creation of short, narrated screencasts to demonstrate research concepts, services, or products. These videos can be embedded into a library online guide or course, posted on a public website, or emailed directly to faculty or students. Adobe Captivate can be used to create more complex, interactive tutorials that allow for student assessment and can be shared in a variety of online formats.

Because the survey data showed that the number of teaching faculty who use Elearning is increasing, the Libraries supported specialized training for the librarians to learn how to use the University's new online learning management system. This has enabled librarians to provide library instruction in this format and to develop a library presence in all online courses. ${ }^{38}$ This Elearning library component offers immediate access to library resources and instructional materials directly from each individual course page. Librarians also plan to provide easy access to customized, discipline-specific resources. It stands to reason that online subject guides or tutorials are more likely to be used by students if they are readily available in their Elearning course pages.

WMU librarians must walk a fine line in Elearning since faculty were not very receptive to having a librarian present in their online courses. To this end, we have also created guidelines for embedding librarians in online courses, including a librarian "role" that allows librarians to view course content and interact with students, but does not allow manipulation of the course itself or viewing of student grades. The expectation is that by providing this limited format for librarians, faculty will feel more comfortable including librarians in their Elearning courses. Incorporating a library presence in Elearning is not without its challenges, but with more and more courses being offered online, this is not an instructional format that librarians can afford to ignore.

Taking a clue from distance education librarians, Pastula (2010) proposes that using a variety of technologies is a wise approach in the delivery of online library instruction. ${ }^{39}$ Luo (2010) provides a practical snapshot of how some academic librarians are employing blogs, wikis, social bookmarking sites, YouTube, and bibliographic management tools for information literacy ${ }^{40}$ Some of the benefits of podcasting outlined by Berk et al. (2007) include its appeal to Millennials and the usefulness for English as a second language (ESL) students or auditory learners who can replay the information at will. ${ }^{41}$ Logically, using technologies that faculty are already familiar with or have successfully used can lead to greater collaboration between faculty and librarians. Since some librarians are more comfortable than others with the new technologies and pedagogical approaches, the WMU Libraries developed a series of training programs to help them improve their mastery of the different technologies. We have also collaborated with the University's online education office to develop workshops for librarians on ways to integrate IL instruction into existing online courses.

\section{Recommendations}

Based on the results of our study, we recommend that librarians consider the following:

- Gather your own data to assess the attitudes and preferences of faculty and students at your own institution, since a "one size fits all" approach will not work across institutions or even across departments within a college.

- Acknowledge that technology supported instruction, such asynchronous instruction, does not necessarily mean the death of face-to-face teaching. For example, students may complete an online tutorial before class, and then use the class period to apply the concepts introduced in the tutorial.

- Use existing technology already in place on your campus. If some faculty are using a particular technology, this may be less intimidating for new adopters and training might be easier to arrange.

- Avoid technology overload by not trying to do everything at once! Choose technology formats that promise to be the most meaningful at your institution.

- Plan for librarian training before implementing a new technology for instruction on a library-wide level. This can also be an opportunity to partner with "tech-savvy" faculty who may already be using this technology.

- Recognize that administrative support is vital when implementing major changes to a program. A number of new technologies not only cost money to purchase, but also may require significant staff time to implement.

- Market continually to alert your faculty to the library's instructional offerings. Tap all possible avenues such as library liaison communication, the library website, emails, newsletters, blogs, and the old tried and true methodword of mouth.

- Assess your program regularly as you put into practice new technologies or instructional formats to measure faculty and student satisfaction, and most importantly, the impact on student learning.

\section{Conclusion}

Not surprisingly, there are several areas that emerged in this study as issues for future research. Research could be conducted on the use of increasingly popular technologies not included in our survey, such as electronic portfolios, online gaming, or simulations, and their potential applications for library instruction. For example, the number of higher education institutions that use electronic portfolios has more than tripled from 13.5 percent in 2003 to 45 percent in 2010. ${ }^{42}$ In addition, it would be valuable to investigate the reasons behind the varying degrees of technological usage by faculty within different disciplines. While an online survey yields useful data, we expect that different perspectives and more in-depth information could be gained by conducting individual interviews and/or focus group discussions, such as those employed by Manuel, Beck, and Molloy. ${ }^{43}$ 
Another important element that needs to be addressed is student attitudes toward technologies. Investigating student opinions toward library instruction and technology in education would be prudent to better align the Libraries' instructional program with current trends. Guidry and BrckaLorenz reported that the NSSE study indicated that students use some technologies markedly more than faculty. In addition, students and faculty may regard technologies and their potential applications in different ways, possibly resulting in strained interactions in the educational setting. ${ }^{44}$ An exploration of the disparity between student and faculty use of technology in the classroom could lead to pedagogical innovations that librarians could apply to increase student engagement and learning, while reducing student anxiety. Once framed, a strategy for delivering library instruction using the most effective technologies cannot remain static, but needs to be frequently refreshed to reflect the ever-evolving higher education technology landscape.

\section{References and Notes}

1. Kenneth C. Green, Campus Computing 2010: The 21st National Survey of Computing and Information Technology in American Higher Education (Encino, CA: Campus Computing Project, 2010), accessed November 15, 2011, http://download.1105media.com/ EDU/ct11/CampusComputing2011.pdf.

2. J. Edmund Maynard, "A Case Study of Faculty Attitudes Toward Library Instruction: The Citadel Experience," Reference Services Review 18, no. 2 (1990): 73.

3. Joy Thomas, "Faculty Attitudes and Habits Concerning Library Instruction: How Much has Changed since 1982?" Research Strategies 12, no. 4 (1994): 209-23.

4. Anita Cannon, "Faculty Survey on Library Research Instruction," RQ 33, no. 4 (1994): 524-41

5. Gloria J. Leckie and Anne Fullerton, "Information Literacy in Science and Engineering Undergraduate Education: Faculty Attitudes and Pedagogical Practices," College \& Research Libraries 60, no. 1 (1999): 9-29.

6. Rhonda Gonzales, "Opinions and Experiences of University Faculty regarding Library Research Instruction: Results of a WebBased Survey at the University of Southern Colorado," Research Strategies 18, no. 3 (2001): 191-201

7. Annmarie B. Singh, "A Report on Faculty Perceptions of Students' Information Literacy Competencies in Journalism and Mass Communication Programs: The ACEJMC Survey," College \& Research Libraries 66, no. 4 (2005): 294-310.

8. Kate Manuel, Susan E. Beck, and Molly Molloy, "An Ethnographic Study of Attitudes Influencing Faculty Collaboration in Library Instruction," Reference Librarian 43, no. 89-90 (2005): 139-61.

9. Paul L. Hrycaj and Michael F. Russo, "A Survey of LSU Faculty Attitudes toward Library Research Instruction," Louisiana Libraries 69, no. 4 (2007): 15-25.

10. Ibid., 15-25.

11. Jacqui Weetman DaCosta, "Is there an Information Literacy Skills Gap to be Bridged? An Examination of Faculty Perceptions and Activities Relating to Information Literacy in the United States and England," College E Research Libraries 71, no. 3 (2010): 203-22.

12. Green, Campus Computing 2010.

13. Jeffrey R. Young, "Reaching the Last Technology Holdouts at the Front of the Classroom," Chronicle of Higher Education, July 25, 2010, http://chronicle.texterity.com/chronicle/20100730a?pg=9\#pg9.

14. Kevin R. Guidry and Allison BrckaLorenz, "A Comparison of Student and Faculty Academic Technology use Across Disci- plines," EDUCAUSE Quarterly 33, no. 3 (2010): 1-12, accessed October 12, 2011, www.educause.edu/EDUCAUSE+Quarterly/ EDUCAUSEQuarterlyMagazineVolum/AComparisonofStudent andFaculty/213682.

15. Patricia McGee and Veronica Diaz, "Wikis and Podcasts and Blogs! Oh, My! What is a Faculty Member Supposed to Do?" EDUCAUSE Review 42, no. 5 (2007): 28-41, accessed November 10, 2011, www.educause.edu/ero/article/wikis-and-podcasts-and -blogs-oh-my-what-faculty-member-supposed-do.

16. SurveyMonkey, www.surveymonkey.com.

17. Cannon, "Faculty Survey," 524-41.

18. Cannon, "Faculty Survey," 524-41; Leckie and Fullerton, "Information Literacy," 9-29; Gonzales, "Opinions and Experiences," 191-201; Hrycaj and Russo, "Survey of LSU Faculty," 15-25.

19. Hrycaj and Russo, "Survey of LSU Faculty," 15-25; Manuel, Beck, and Molloy, "Ethnographic Study," 139-161.

20. Hrycaj and Russo, "Survey of LSU Faculty," 15-25; Singh, "Report on Faculty," 294-310.

21. Maynard, "Case Study of Faculty," 67-76; Larry Hardesty, "Faculty Culture and Bibliographic Instruction: An Exploratory Analysis," Library Trends 44, no. 2 (1995): 339-67; Leckie and Fullerton, "Information Literacy," 9-29; Devin Feldman and Susan Sciammarella, "Both Sides of the Looking Glass: Librarian and Teaching Faculty Perceptions of Librarianship at Six Community Colleges," College \& Research Libraries 61, no. 6 (2000): 491-98.

22. Paul Hrycaj and Michael Russo, "Reflections on Surveys of Faculty Attitudes Toward Collaboration with Librarians," Journal of Academic Librarianship 33, no. 6 (2007): 692-96; Thomas, "Faculty Attitudes," 209-23.

23. Constance A. Mellon, "Library Anxiety: A Grounded Theory and its Development," College E Research Libraries 47, no. 2 (1986): 163.

24. Evan I. Farber, "Working with Faculty: Some Reflections," College E Undergraduate Libraries 11, no. 2 (2004): 131.

25. Manuel, Beck, and Molloy, "Ethnographic Study," 139-61.

26. Leckie and Fullerton, "Information Literacy," 9-29.

27. William B. Badke, "Can't Get no Respect: Helping Faculty to Understand the Educational Power of Information Literacy," Reference Librarian no. 89/90 (2005): 70.

28. Green, Campus Computing 2010.

29. Young, "Reaching the Last Technology."

30. Amanda Lenhart, memorandum, January 14, 2009, Pew Internet and American Life Project, accessed October 16, 2011, www .pewinternet.org/ /media//Files/Reports/2009/PIP_Adult_social _networking_data_memo_FINAL.pdf.pdf.

31. Shannon D. Smith and Judith Borreson Caruso, Key Findings: The ECAR Study of Undergraduate Students and Information Technology, 2010 (EDUCAUSE Center for Applied Research, October 2010), accessed October 25, 2011, http://net.educause.edu/ir/library/ pdf/EKF/EKF1006.pdf.

32. Green, Campus Computing 2010.

33. Young, "Reaching the Last Technology."

34. Smith and Caruso, Key Findings.

35. Guidry and BrckaLorenz, "A Comparison of Student," 1-12.

36. ResearchPath, Western Michigan University online tutorial, http:// libguides.wmich.edu/home.

37. Jing, TechSmith Corporation, http://www.techsmith.com/jing .html; Adobe Captivate, Adobe Systems Incorporated, www adobe.com/products/captivate.html.

38. Western Michigan University adopted the Desire2Learn learning management system in the summer of 2011. Desire2Learn Incorporated, D2L Ltd., www.desire2learn.com.

39. Matthew Pastula, "Use of Information and Communication Technology to Enhance the Information Literacy Skills of Distance Students," Journal of Library \& Information Services In Distance Learning 4, no. 3 (2010): 77-86.

40. Lili Luo, "Web 2.0 Integration in Information Literacy Instruc- 


\section{FEATURE}

tion: An Overview," Journal of Academic Librarianship 36, no. 1 (2010): 32-40.

41. Jaya Berk et al., "Innovation in a Podshell: Bringing Information Literacy into the World of Podcasting," Electronic Library 25, no.
4 (2007): 409-19.

42. Green, Campus Computing 2010.

43. Manuel, Beck, and Molloy, "Ethnographic Study," 139-61.

44. Guidry and BrckaLorenz, "A Comparison of Student," 1-12.

\section{APPENDIX. SURVEY ADMINISTERED TO WMU FACULTY}

1. Your department

2. Years taught at the post-secondary level:

_ Less than 2

$-2-5$

- $6-10$

$-11-20$

- 21 and up

3. Status at WMU:

Full-time faculty

_ Part-time/adjunct faculty

_ Graduate student instructor (GA/TA)

4. How have you used eLearning (Learning Management System such as Blackboard, WebCT, or Desire 2 Learn) in your teaching? (check all that apply)

_ Online class_class taught entirely through eLearning

_ Hybrid—some class sessions in person, but majority of instruction through eLearning

_ Supplemental_-traditional face-to-face class, with additional material posted on eLearning

_. I have never used eLearning

_ Other (please explain)

5. Which of the following technologies have you used in your college teaching? (check all that apply)

_ Online or embedded videos

_ Podcasts

_ Blogs

_ RSS feeds

- Wikis

_ Discussion boards/forums

__ Personal Web page or WMU "Homepage"

_ Video conferencing

_ iClickers

_ Electronic Reserve items

_ Social Networking Sites (Facebook, Twitter, Delicious, etc.)

_ Other (please explain)

6. Which technologies did you find successful or unsuccessful in your classroom teaching? Why?

7. Do you have assignments in your courses that require your students to search for and use information beyond the textbook and assigned course readings? (e.g. scholarly publications, library resources, Internet sites, etc.)

_ All of my courses

_ Most of my courses

_ About half of my courses

_ Only a few of my courses

_ None of my courses 
8. How do you rate your students' ability to find and evaluate relevant information available through the University Libraries?

\begin{tabular}{|l|l|l|l|l|l|l|}
\hline & Excellent & Good & Satisfactory & Marginal & Unsatisfactory & N/A \\
\hline $\begin{array}{l}\text { Freshmen/ } \\
\text { Sophomores }\end{array}$ & & & & & & \\
\hline Juniors/Seniors & & & & & & \\
\hline Graduate Students & & & & & & \\
\hline
\end{tabular}

9. How do you rate your students' ability to find and evaluate relevant information available through other means (such as the Internet, Google, etc.)?

\begin{tabular}{|l|l|l|l|l|l|l|}
\hline & Excellent & Good & Satisfactory & Marginal & Unsatisfactory & N/A \\
\hline $\begin{array}{l}\text { Freshmen/ } \\
\text { Sophomores }\end{array}$ & & & & & & \\
\hline Juniors/Seniors & & & & & & \\
\hline Graduate Students & & & & & & \\
\hline
\end{tabular}

How important do you feel it is for WMU students to have the following skills:

\begin{tabular}{|l|l|l|l|l|}
\hline & $\begin{array}{c}\text { Very } \\
\text { important }\end{array}$ & Important & $\begin{array}{c}\text { Minimally } \\
\text { important }\end{array}$ & $\begin{array}{c}\text { Not at all } \\
\text { important }\end{array}$ \\
\hline Develop a workable research question/statement & & & & \\
\hline $\begin{array}{l}\text { Select and use appropriate tools to find information (books, } \\
\text { articles, databases, Internet sources, etc.) }\end{array}$ & & & & \\
\hline $\begin{array}{l}\text { Evaluate } \\
\text { information sources }\end{array}$ & & & & \\
\hline Correctly cite sources & & & & \\
\hline Avoid plagiarism & & & & \\
\hline
\end{tabular}

10. Have you taken advantage of library research instruction for your courses in any of these formats? (Check all that apply) _ Brought class to library

_ Librarian came to my classroom

_ Students voluntarily attended research session scheduled outside of class time

__ Librarian created class guide for my specific course

_ Librarian-developed online tutorial, video podcasts, or other online instruction

_ Librarian presence in my eLearning course (e.g., interacted in discussion board, posted instructional materials, etc.)

_ Librarian "met" with class via video conference or Webinar format

_ I have not done any form of library instruction

_ Other form of instruction (please explain) 


\section{FEATURE}

11. How interested would you be in using these types of library research instruction in the future?

\begin{tabular}{|c|c|c|c|}
\hline & Very interested & $\begin{array}{l}\text { Somewhat } \\
\text { interested }\end{array}$ & $\begin{array}{l}\text { Not at all } \\
\text { interested }\end{array}$ \\
\hline \multicolumn{4}{|l|}{ Bring class to library } \\
\hline \multicolumn{4}{|l|}{ Librarian teach class in my classroom (less than $\mathbf{3 0}$ minutes) } \\
\hline \multicolumn{4}{|l|}{ Librarian teach class in my classroom (30 minutes or more) } \\
\hline \multicolumn{4}{|l|}{$\begin{array}{l}\text { Students voluntarily attend research session scheduled } \\
\text { outside of class time }\end{array}$} \\
\hline \multicolumn{4}{|l|}{ Librarian create class guide for my specific course } \\
\hline \multicolumn{4}{|l|}{$\begin{array}{l}\text { Librarian-develop online tutorial, video podcasts, or other } \\
\text { online instruction }\end{array}$} \\
\hline \multicolumn{4}{|l|}{$\begin{array}{l}\text { Librarian participate in my eLearning course (e.g., interact in } \\
\text { discussion board, post instructional materials, etc.) }\end{array}$} \\
\hline \multicolumn{4}{|l|}{$\begin{array}{l}\text { Librarian "meet" with class via video conference or Webinar } \\
\text { format }\end{array}$} \\
\hline Other form of instruction (please explain) & & & \\
\hline
\end{tabular}

12. Have you taken advantage of a library research instruction session in the last four years?

- Yes

- No

13. If you have not taken advantage of library research instruction in the past four years, please tell us why. (Check all that apply)

_- Do not want to give up class time

_ Not relevant to my courses

_ I was not aware of this service

_ I prefer to teach these concepts myself

_ My students have told me that they already understand the research concepts

_ Students have already learned these concepts in an earlier class

_ It is my students' responsibility to learn the research concepts on their own

_ Other (please explain)

14. If you tried a library research instruction session before, did you find it useful?

- Yes

- No

15. What did you find useful about the library research instruction session?

16. Why did you not find the library research instruction session useful?

17. Do you have any suggestions for improving library research instruction services at WMU?

18. Any final comments? 